\title{
SCIENTIFIC VALIDATION OF SASTRIC SIDDHA DRUG MANJAL KAMALAI KIYAZHAM AGAINST PARACETAMOL INDUCED HEPATOTOXICITY IN ZEBRA FISH (DANIO RERIO) MODEL
}

\author{
GOMATHI $\mathbf{R}^{1 *}$, PREETHEEKHA $\mathrm{E}^{2}$, SHANMUGA PRIYA $\mathrm{P}^{3}$, MAMALLAN $\mathrm{A}^{4}$ \\ ${ }^{1}$ Department of Maruthuvam, National Institute of Siddha, Chennai, Tamil Nadu, India. ${ }^{2}$ Department of Kuzhanthai Maruthuvam, National \\ Institute of Siddha, Chennai, Tamil Nadu, India. ${ }^{3}$ Department of Nanju Maruthuvam, National Institute of Siddha, Chennai, Tamil Nadu, India. \\ ${ }^{4}$ Department of Gunapadam, Mallankinaru Primary Health Centre, Virudhunagar, Tamil Nadu, India. Email: kgmgomathi@gmail.com
}

Received: 30 September 2020, Revised and Accepted: 04 January 2021

ABSTRACT

Objective: The objective of this study is to assess the hepatoprotective nature of Siddha formulation manjal noi kudineer (MNK) against Paracetamol induced hepatotoxicity in Zebrafish Danio rerio model.

Methods: Pharmacological studies were carried out in the adult zebra fish model in the category of four groups; each individual group contained ten animals. Groups 1, 2, 3, and 4 were considered as control groups, disease control groups, and drug treated groups at different concentrations, respectively. Histopathological analysis was recorded.

Results: The observed research findings were confirmed that this novel Siddha formulation MNK possess potent hepatoprotective effect at the both dose level of $250 \mathrm{mg} / \mathrm{l}-500 \mathrm{mg} / \mathrm{l}$ against paracetamol induced toxicity in Zebrafish.

Conclusion: Siddha medicinal formulation has been in practice for more than 1000 years. Liver diseases are the highly prevalent one among all the diseases. Although huge drugs are available for liver diseases, there is a need for cost effectiveness drugs without any adverse effect. From the study, it was concluded that the drug MNK has promising hepatoprotective activity in dose-dependent manners and restores the basic liver architecture by means of its rejuvenating potential against paracetamol induced toxicity in Zebrafish model. We can strongly suggest that the Sastric Siddha drug MNK to treat various kinds of liver diseases such as liver cirrhosis and hepatic carcinoma. This research work may be highly beneficial to the people who suffered from various liver diseases if the drug will be given clinically.

Keywords: Siddha medicine, Poly herbal, Traditional, Sastric, Hepatoprotective, Kudineer.

(C) 2021 The Authors. Published by Innovare Academic Sciences Pvt Ltd. This is an open access article under the CC BY license (http://creativecommons.org/ licenses/by/4.0/) DOI: http://dx.doi.org/10.22159/ajpcr.2021v14i3.39901. Journal homepage: https://innovareacademics.in/journals/index.php/ajpcr

\section{INTRODUCTION}

In Siddha system of medicines, the diseases on the liver are referred as "Kalleeral noikal." Management of Viral hepatitis in the Siddha medical system is still a magical wonder by the way of its admirable therapeutic values. According to Siddha medical pathology the hepatic diseases are caused based on the abnormalities seen in the bodily Vital humors Pitham and Kapham. The formulations were made by Siddhars according to the concept of "Arusuvai." The prevalence of hepatic carcinoma, liver failure, cirrhosis of the liver, and viral hepatitis is seems to be very high. Globally, 2 million liver death accounts every year mainly because of liver cirrhosis, viral hepatitis, and hepatic carcinoma [1].

Liver metabolism plays a significant role in our day-to-day human life. Sometimes even the medications also give some trouble to our health. The liver might be considered as the most significant organ in drug harmfulness since it is practically mediated between the site of absorption and the systemic blood circulation and is a significant site of metabolism and disposal of unfamiliar substances; these highlights render it a favored objective for drug poisonousness. Drug-induced liver injury (DILI) therefore poses a major clinical problem. DILI is started by direct hepatotoxic impacts of a medication, or a receptive metabolite of a medication. Various plants having hepatoprotective property and those are considered as a very rich source to treat liver diseases [2]. Some herbals in Siddha medicine such as Curcuma Longa, Wedelia Sinensis, and Terminalia chebula claim high for its hepatoprotective effects. Likewise various herbo mineral and herbo metallic formulations were given by great Siddhars to treat different kinds of diseases on the liver without causing any adverse effects. Even though Sastric Siddha drugs are highly therapeutic in its action, preclinical and clinical evidences have to be investigated to explore its potent medicinal value all over the world. Drug induced toxicity can be easily evaluated in Zebrafish model [3].

Among many Siddha formulations, Manjal noi kudineer (MNK) is a best drug in the management of livers disorders. Although it was indicated in Sastric literatures, still there is no scientific background claiming its hepatoprotective effect. Here an attempt is made to evaluate the hepatoprotective effect of MNK in the Zebrafish model using paracetamol induced hepatotoxicity.

\section{METHODS}

The Siddha formulation MNK was prepared as per the Sastric Siddha book entitled [4]. The details of the ingredients are shown in Table 1.

\section{Preparatory methods of drug sample MNK}

Drugs were purchased from Earth India naturals, a Good Manufacturing Practices certified company. All the ingredients were taken into equal quantity, then dried and grinded into a coarse powder. With the use of water the test drug, MNK was prepared as per the Siddha texts. The images of the drug MNK raw drug and decoction were shown below in (Figs. 1 and 2).

\section{Pharmacological-experimental section methodology} Animal

The laboratory Adult Zebrafish (Danio rerio) were purchased from the nearby aquarium and were maintained in a laboratory condition $28^{\circ} \mathrm{C} \pm 1^{\circ} \mathrm{C}$ for a period of $14: 10 \mathrm{~h}$ light/dark cycle photoperiod. All fishes were acclimatized to standard lab condition 4 weeks before the start of experimentation. Animals were divided into four groups of ten fish 
Table 1: Details of herbs formulated in Siddha drug MNK

\begin{tabular}{|c|c|c|c|c|c|}
\hline Sl.no & $\begin{array}{l}\text { Plant name } \\
\text { (Tamil name) }\end{array}$ & Parts used & Botanical name & Family name & Biological property \\
\hline \multirow[t]{4}{*}{1} & Keezhkaai Nelliver & Root & Phyllanthus amarus & Phyllanthaceae & 1. Hepatoprotective effect [5] \\
\hline & & & & & 2. Anti-oxidant activity [6] \\
\hline & & & & & 3. Growth inhibitory activity on cancer cell lines [7] \\
\hline & & & & & 4. Increase lifespan on Hepatocellular carcinoma [8] \\
\hline \multirow[t]{2}{*}{2} & Sirunerinjil Vaer & Root & Tribulus terrestris & Zygophyllaceae & 1. Hepatoprotective [9-11] \\
\hline & & & & & 2. Antioxidant activity [12]. \\
\hline \multirow[t]{4}{*}{3} & Seeragam & Dried fruits & Cuminum сутіnum & Apiaceae & 1. Anti-inflammatory effect [13] \\
\hline & & & & & 2. Antioxidant activity [14] \\
\hline & & & & & 3. Hepatoprotective activity [15] \\
\hline & & & & & 4. Anticancer activity [16] \\
\hline \multirow[t]{3}{*}{4} & Pei Pudal & whole plant & Trichosanthes dioica & Cucurbitaceae & 1. Immunomodulating effect [17] \\
\hline & & & & & 2. Hepatoprotective effect [18] \\
\hline & & & & & 3. Antioxidant activity [19] \\
\hline \multirow[t]{3}{*}{5} & Vilvamver & Root & Aegle marmelos & Rutaceae & 1. Anticancer Effect [20] \\
\hline & & & & & 2. Hepatoprotective activity [21] \\
\hline & & & & & 3. Antioxidant activity $[22,23]$ \\
\hline \multirow[t]{3}{*}{6} & Sirukeerai Ver & Root & Amaranthus tricolor & Amaranthaceae & 1. Hepatoprotective Activity [24] \\
\hline & & & & & 2. Anticancer Effect [25] \\
\hline & & & & & 3. Antimicrobial and antioxidant activities $[26,27]$ \\
\hline \multirow[t]{5}{*}{7} & Karisalankanni & whole plant & Eclipta prostrata & Asteraceae & 1. Hepatoprotective activity $[28,29]$ \\
\hline & & & & & 2. Anticancer activity [30] \\
\hline & & & & & 3. Antifibrotic effects [31] \\
\hline & & & & & 4. Antimicrobial activity [32] \\
\hline & & & & & 5. Antiproliferative activity [33] \\
\hline \multirow[t]{3}{*}{8} & Valmilagu & Seed & Piper nigrum & Piperaceae & 1. Immunomodulatory effect [34] \\
\hline & & & & & 2. Antihepatotoxic effect [35] \\
\hline & & & & & 3. Antioxidant effect [36] \\
\hline \multirow[t]{2}{*}{9} & Sombu & Dried fruits & Foeniculum vulgare & Apiaceae & 1. Antioxidant effect, anticarcinogenic effect [37] \\
\hline & & & & & 2. Hepatoprotective effect $[38,39]$. \\
\hline
\end{tabular}

MNK: Manjal noei kudineer

each. The weight $/ \mathrm{ml}$ calculation of the drug MNK=0.050 gm (5000 mg or $50 \mathrm{mg}) / \mathrm{ml}$.

Grouping

- Group I: Control

- Group II: Paracetamol 5 mM (755.8 mg) per liter concentration

- Group III: Paracetamol 5 mM+MNK Low Dose 250 mg/l

- Group IV: Paracetamol 5 mM+MNK High Dose 500 mg/l.

\section{Treatment}

Animal belongs to Group I left untreated and Group II treated with Paracetamol at the concentration of $5 \mathrm{mM}(755.8 \mathrm{mg})$ per liter concentration for the period of 7 days. Animal belongs to Group III received test drug MNK at the concentration of $250 \mathrm{mg} / \mathrm{l}$ and Group IV received test drug MNK at the concentration of $500 \mathrm{mg} / \mathrm{l}$ along with paracetamol $5 \mathrm{mM}$ for the period of 7 days.

\section{Histopathology}

After a 1-week exposure period, fishe were sacrificed and the livers of Zebrafish were dissected and fixed in $10 \%$ formalin at $4^{\circ} \mathrm{C}$ for $24 \mathrm{~h}$. Subsequently, the fixed liver tissues were dehydrated in gradient ethanol, hyalinized in xylene, and embedded in paraffin wax at $56^{\circ} \mathrm{C}$. At that point, the paraffin blocks were separated at $4-\mu \mathrm{m}$ thickness. The segments were gathered on glass slides and recolored with hematoxylin and eosin ( $\mathrm{H}$ and $\mathrm{E})$ utilizing a $\mathrm{H}$ and $\mathrm{E}$ Staining Kit. Histologic lesions were watched utilizing an optical microscope instrument outfitted with a computerized camera.

\section{RESULTS AND DISCUSSION}

The histological microscopy findings belong to the normal control Group I (Fig. 3) show the presence of regularly arranged hepatocytes exist in polygonal shape cells and with prominent nucleus further sinusoids appears with regular intervals. In Group II (Fig. 4), severe discrete

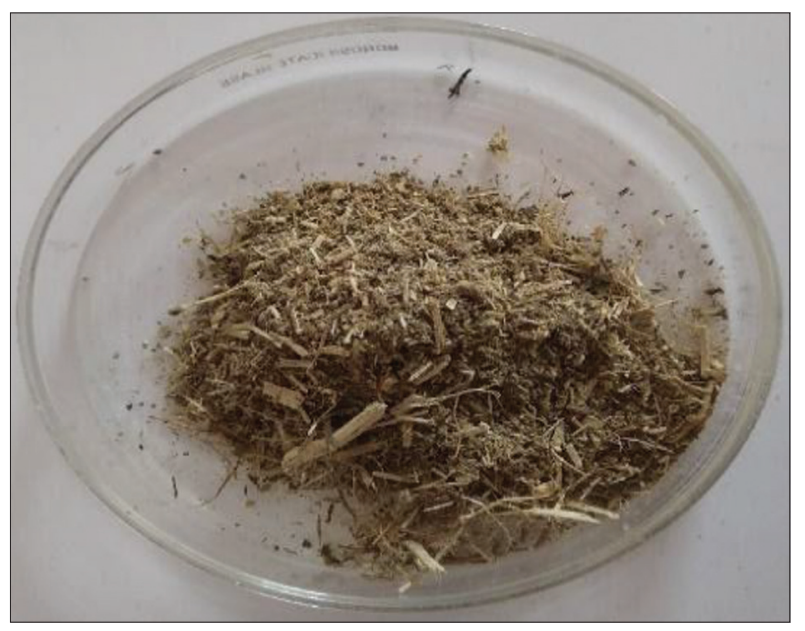

Fig. 1: Manjal noi kudineer-raw drug

cytoplasmic vacuoles and rare foamy cytoplasm were observed. This prominence indicates the presence of inflammatory changes in it. The histopathological findings of Group III (Fig. 5) retain the basic structure of polygonal shaped hepatic parenchyma with occasional Pyknotic nuclei and of Group IV (Fig. 6) shows that regenerated liver cells with Occasional bi nucleated hepatocytes were observed. This is due to the hepatoprotective nature of the drug MNK treated. The reasons behind the hepatoprotective effect of this formulation are possibly due to the presence of herbals in it. One pharmacological research findings confirms that the aqueous extract of Phyllanthus niruri exhibits hepatoprotective effects against carbon tetrachloride induced liver toxicity in mice. The herbals T. terrestris and Bauhinia acuminata present in this formulation were already documented for its immunomodulatory effects. In addition 


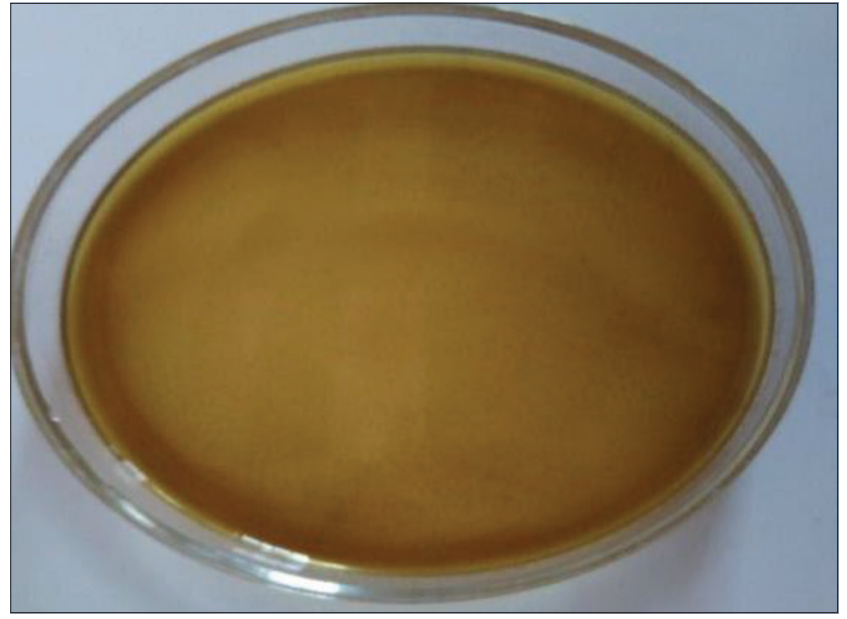

Fig. 2: Manjal noi kudineer-kudineer decoction

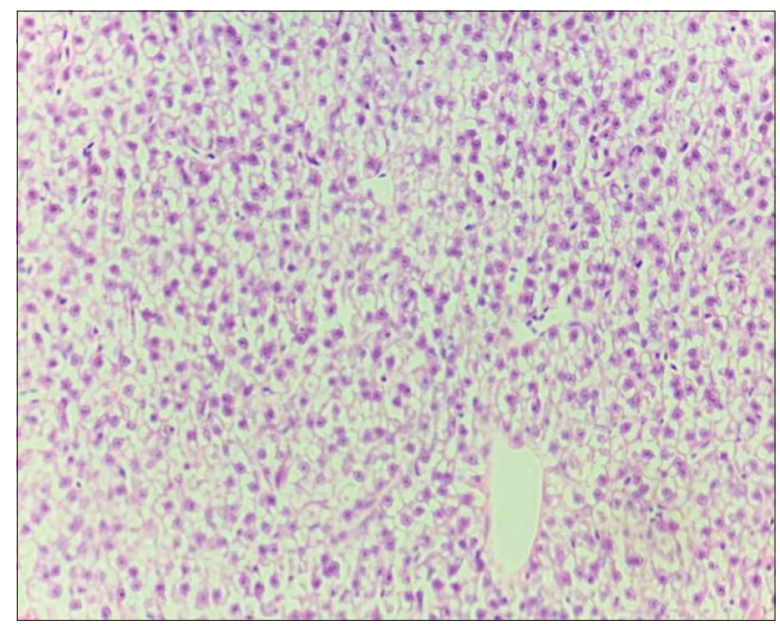

Fig. 3: Group I (Normal Control)

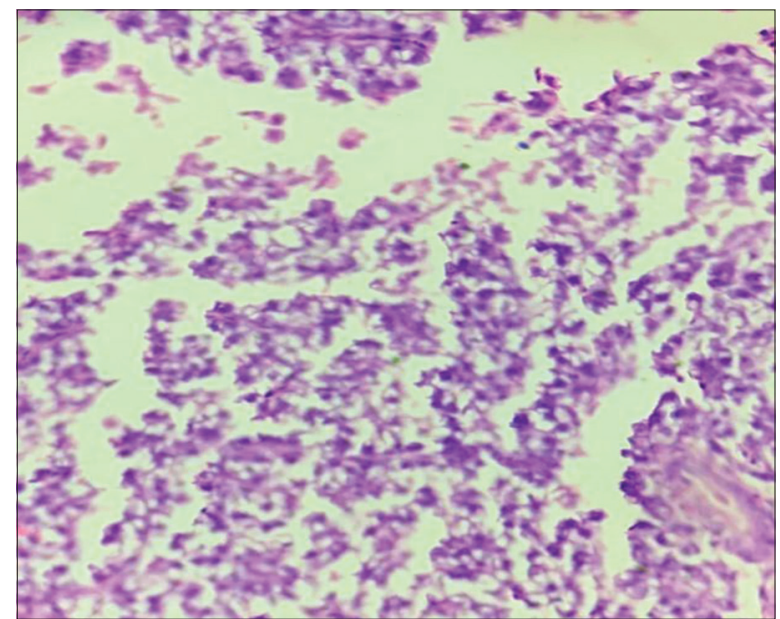

Fig. 4: Group II (Disease Control)

to that the other herbal ingredients present in this formulation have antiinflammatory, antioxidant activity was identified through pharmacological action. All these beneficial effects of this plant significantly may have therapeutic values to treat hepatic diseases. The flavonoids and other phytochemical constituents present in the herbals of this formulation may be the factors behind the hepatoprotective effect of this siddha drug MNK.

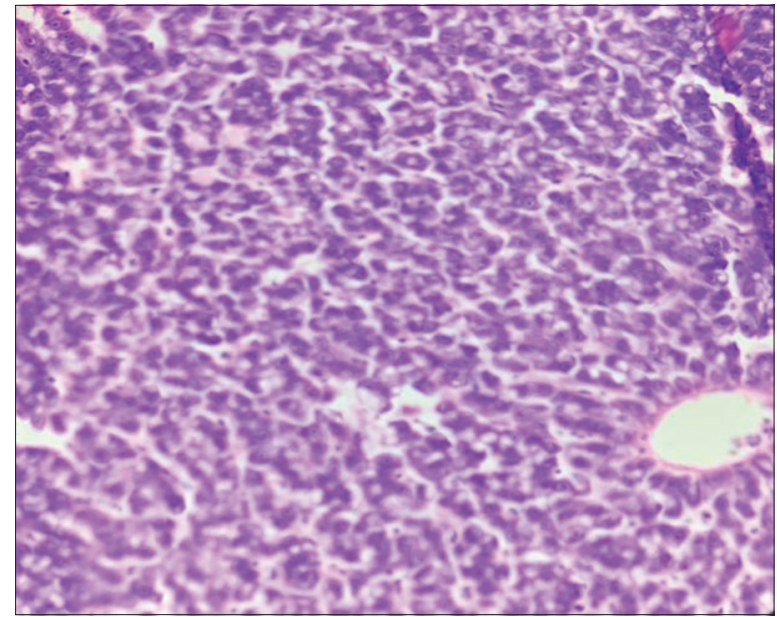

Fig. 5: Group III (Low dose of manjal noi kudineer treatment)

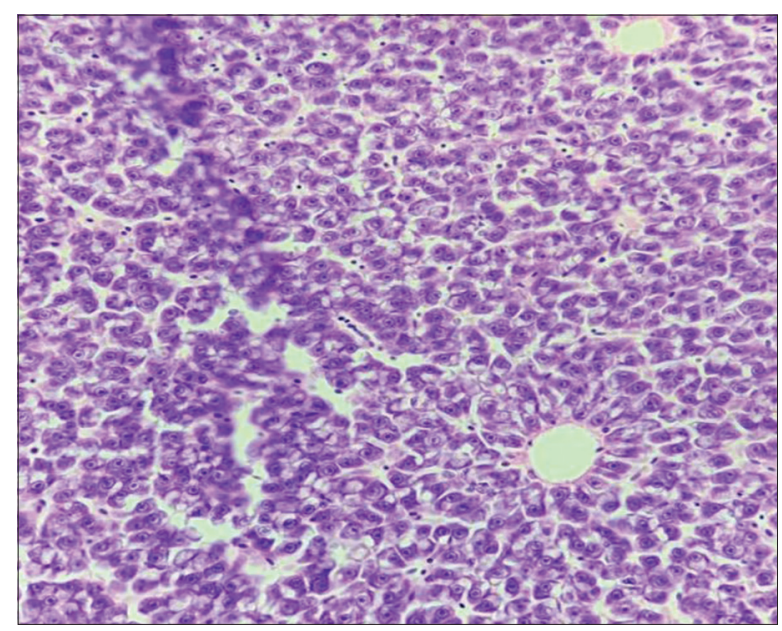

Fig. 6: Group IV (High dose of manjal noi kudineer treatment)

\section{CONCLUSION}

The results of the present investigation indicate that paracetamol treated groups show severe liver degeneration and inflammation associated fibrosis whereas treatment with test drug MNK at both the dose levels fundamentally constricted the paracetamol prompted harm in Groups III and IV. Hence, from the study, it was concluded that the drug MNK has promising hepatoprotective activity in dosedependent manners and restores the basic liver architecture by means of its rejuvenating potential against paracetamol induced toxicity in Zebrafish model. We can strongly suggest that the Sastric Siddha drug MNK to treat various kinds of liver diseases such as liver cirrhosis and hepatic carcinoma; however, further study is required to identify the hepatoprotective constituents present in the formulation as well as elucidating the mechanism of action.

\section{CONFLICTS OF INTEREST STATEMENT}

No conflicts of interest.

\section{FINANCIAL SUPPORT AND SPONSORSHIP}

Nil.

\section{ACKNOWLEDGMENT}

Our sincere thanks to Palpandian, Dr. Thamodaran, Dr. Balasubramanian, Dr. Natarajan, Rathinambal for their constant support. 


\section{AUTHOR CONTRIBUTION}

This study was designed, directed, and coordinated by principal investigator provided conceptual and technical guidance for all aspects of the project by Dr. R. Gomathi, Dr. E. Preetheekha, Dr. P. Shanmuga Priya, and Dr. A. Mamallan Suggested and commented on the design of the experiments.

\section{REFERENCES}

1. Sumeet A, Harshad D, John E, Patrick K. Burden of liver diseases in the world. J Hepatol 2018;70:151-71.

2. Kunle O, Uchechukwu N, Leonard M, Anthony O. A review on some medicinal plants with hepatoprotective effects. Pharmacogn Rev 2018;12:186.

3. McGrath P, Li CQ. Zebrafish: A predictive model for assessing druginduced toxicity. Drug Discov Today 2008;13:394-401.

4. Pillai K. Parambarai Vaidyam. Chennai: Rathina Naiker and Sons; 1982. p. 54

5. Pramyothin P, Ngamen C, Poungshompoo S, Chaichantipyuth C. Hepatoprotective activity of Phyllanthus amarus Schum. et. Thonn. extract in ethanol treated rats: In vitro and in vivo studies. J Ethnopharmacol 2007;114:169-73.

6. Karuna R, Reddy SS, Baskar R, Saralakumari D. Antioxidant potential of aqueous extract of Phyllanthus amarus in rats. Indian J Pharmacol 2009;41:64-7.

7. Araújo RF Jr., Soares LA, da Costa Porto CR, de Aquino RG, Guedes HG, Petrovick PR, et al. Growth inhibitory effects of Phyllanthus niruri extracts in combination with cisplatin on cancer cell lines. World J Gastroenterol 2012;18:4162-8.

8. Rajeshkumar NV, Kuttan R. Phyllanthus amarus extract administration increases the life span of rats with hepatocellular carcinoma. J Ethnopharmacol 2000;73:215-9.

9. Palanivel K, Ramar R, Bupesh G, Stalin A. Hepatoprotective activity of Tribulus terrestris extract against acetaminophen-induced toxicity in a freshwater fish (Oreochromis mossambicus). In vitro cellular and developmental biology. Animal 2011;47:698-706.

10. Sugunavarman T, Jegadeesan G. Hepatoprotective activity of Tribulus terrestris on experimental liver damage mice. Int $\mathrm{J}$ Mod Res Rev 2013;1:20-3.

11. Kavitha P, Ramesh R, Bupesh G, Stalin A, Subramanian P. Hepatoprotective activity of Tribulus terrestris extract against acetaminophen-induced toxicity in a freshwater fish (Oreochromis mossambicus). In Vitro Cell Dev Biol Anim 2011;47:698-706.

12. Harraz FM, Ghazy NM, Hammoda HM, Nafeaa AA, Abdallah II. Hepatoprotective and antioxidant activities of Tribulus terrestris. J Physiol Pharmacol Adv 5:787-94.

13. Shivakumar S, Shahapurkar A, Kalmath K, Shivakumar B. Antiinflammatory activity of fruits of Cuminum cyminum Linn. Pharm Lett 2010;2:22-4.

14. Rebey IB, Jabri-Karoui I, Hamrouni-Sellami I, Bourgou S, Limam F, Marzouk B. Effect of drought on the biochemical composition and antioxidant activities of cumin (Ситіпит cyminum L.) seeds. Ind Crops Prod 2011;36:238-45

15. Kode A, Rajagopalan R, Penumathsa SV, Menon VP. Effect of ethanol and thermally oxidized sunflower oil ingestion on phospholipid fatty acid composition of rat liver: Protective role of Cuminum cyminum L. Ann Nutr Metab 2005;49:300-3.

16. Goodarzi S, Tabatabaei MJ, Jafari RM, Shemirani F, Tavakoli S, Mofasseri M, et al. Cuminum cyminum fruits as source of luteolin-7-Oglucoside, potent cytotoxic flavonoid against breast cancer cell lines. J Nat Prod Res 2020;34:1602-6.

17. Bhadoriyal SS, Mandoriyab N. Immunomodulatory effect of Trichosanthes dioica Roxb. Asian Pac J Trop Biomed 2012;2:S985-7.

18. Gupta RK, Swain SR, Sahoo J, Gupta A, Chaudhary S. Hepatoprotective potential of Trichosanthes dioica Roxb in hepatotoxicity induced by simvastatin and its consequences on biochemical and haematological indices. Pharmacogn J 2018;10:720-4.

19. Tanwar M, Sharma A, Swarnkar KP, Singhal M. Antioxidant and hepatoprotective activity of Trichosanthes dioica roxb. on paracetamol induced toxicity. Int J Pharm Stud Res 2018;10:720-4.

20. Seemaisamy R, Faruck LH, Gattu S, Neelamegam R, Bakshi HA, Ration L, et al. Anti-microbial and anti-cancer activity of Aegle Marmelos and gas chromatography coupled spectrometry analysis of their chemical constituents. Int J Pharm Sci Res 2019;10:373-80.

21. Sumitha P, Thirunalasundari T. Hepatoprotective activity of Aegle marmelos in $\mathrm{CCl}_{4}$ induced toxicity an in-vivo study. J Phytol 2011;3:5-9.

22. Siddique N, Mujeeb M, Najmi A, Aftab A, Aslam J. Free radical scavenging and hepatoprotective activity of Aegle marmelos (Linn.) Corr leaves against carbon tetrachloride. Int J Comprehen Pharm 2011.

23. Singh RP, Banerjee S, Rao R. Effect of Aegle marmelos on biotransformation enzyme systems and protection against free-radicalmediated damage in mice. J Pharm Pharmacol 2010;52:991-1000.

24. Al-Dosari MS. The effectiveness of ethanolic extract of Amaranthus tricolor L.: A natural hepatoprotective agent. Am J Chin Med 2010;38:1051-64.

25. Jayaprakasam B, Zhang Y, Nair MG. Tumor cell proliferation and cyclooxygenase enzyme inhibitory compounds in Amaranthus tricolor. J Agric Food Chem 2004;52:6939-43.

26. Rao KN, Padhy SK, Dinakaran SK, Banji D. Study of pharmacognostic, phytochemical, antimicrobial and antioxidant activities of Amaranthus tricolor Linn. leaves extract. Iran J Pharm Sci Autumn 2010;6:289-99.

27. Alam S, Krupanidhi K, Rao KR. Evaluation of in-vitro antioxidant activity of Amaranthus tricolor Linn. Asian J Pharmacol Toxicol 2013;1:12-6.

28. Lin SC, Yao CJ, Lin CC. Hepatoprotective activity of Taiwan folk medicine: Eclipta prostrate Linn. against various hepatotoxins induced acute hepatotoxicity. Phytother Res 1996;10:483-90.

29. Manvar D, Mishra M, Kumar S, Pandey VN. Identification and evaluation of anti-hepatitis $\mathrm{C}$ virus phytochemicals from Eclipta alba. J Ethnopharmacol 2012;144:545-54.

30. Chaudhary H, Dhuna V, Singh J, Kamboj SS, Seshadri S. Evaluation of hydro-alcoholic extract of Eclipta alba for its anticancer potential: An in vitro study. J Ethnopharmacol 2011;136:363-7.

31. Chen YZ, Chen J, Cao Y, Xu C, Li R, Pan Y, et al. Wedelolactone exhibits anti-fibrotic effects on human hepatic stellate cell line LX-2. Eur J Pharmacol 2013;714:105-11.

32. Rahman MS, Rashid MA. Antimicrobial activity and cytotoxicity of Eclipta prostrata. Orient Pharm Exp Med 2008;8:47-52.

33. Lee MK, Ha NR, Yang H, Sung SH, Kim GH, Kim YC. Antiproliferative activity of triterpenoids from Eclipta prostrate on hepatic stellate cells. Phytomedicine 2008; 15:775-80.

34. Mohamed MS, Jaikumar K, Anand S, Saravanan P. Assessment of cytotoxic and immunomodulatory properties of Piper nigrum Linn. (White Pepper) seed extract. Int J Pharm Sci Drug Res 2017;9:64-7.

35. Bai X, Zhang W, Chen W, Zong W, Guo Z, Liu X. Anti-hepatotoxic and antioxidant effects of extracts from Piper nigrum. Afr J Biotechnol 2011;10:267-72.

36. Ahmad N, Fazal H, Abbasi BH, Haider B, Muhammad R. Efficient regeneration and antioxidant potential in regenerated tissues of Piper nigrum L. Plant Cell Tiss Organ Cult 2010;102:129-34.

37. Mohamad RH, El-Bastawesy AM, Abdel-Monem MG, Noor AM, AlMehdar HA, Sharawy SM, et al. Antioxidant and anticarcinogenic effects of methanolic extract and volatile oil of fennel seeds (Foeniculum vulgare). J Med Food 2011;14:986-1001.

38. Özbek H, Uğraş S, Dülger H, Bayram I, Tuncer T, Oztürk G, et al. Hepatoprotective effect of Foeniculum vulgare essential oil: A carbontetrachloride induced liver fibrosis model in rats. Scand J Lab Anim Sci 2004;31:317-9.

39. Mansour SA, Heikal TM, Refaie AA, Mossa AT. Antihepatotoxic activity of fennel (Foeniculum vulgare Mill.) essential oil against chlorpyrifos-induced liver injury in rats. Glob J Environ Sci Technol 2011;1:10. 